\title{
EFFECT OF PULSING IN PRESERVATIVE SOLUTIONS, GROWTH REGULATORS AND COLD STORAGE TREATMENTS ON THE LONGEVITY OF LILY CUT FLOWERS CV. BORSA
}

\author{
Nermeen M. Badawy ${ }^{1}$; Sohaier E. Hassan ${ }^{2}$; H.A.S. El-Shoura ${ }^{2}$; \\ M.H.M. El-Shreif ${ }^{3}$ and Fatma El-Napwya M. El-Quesni ${ }^{1}$
}

1- Biological and Agricultural Research Division, Department of Ornamental Plants and Woody Trees, National Research Center, Dokki, Giza, Egypt

2- Department of Horticulture, Faculty of Agriculture, Ain Shams University, Cairo, Egypt

3- Department of Botany, Faculty of Agriculture, Ain Shams University, Cairo, Egypt

*Corresponding author, email: aleman kair@yahoo.com

Keywords: Lilium hybrida, Pulsing, Preservative solutions, Growth regulators, Cold storage, Longevity, Lily, Cut flowers

\section{ABSTRACT}

The interaction of preservations, growth regulators and cold storage on vase life and quality of Lily (Lilium longiflorum) cut flowers were investigated. Lily cut flowers were treated with $1 \mathrm{ml} \mathrm{mol}$ silver thiosulfate (STS), 100 ppm gibberellic acid $\left(\mathrm{GA}_{3}\right), 0.5 \mathrm{ml} \mathrm{mol}$ benzyl adenine (BA), $200 \mathrm{ppm}$ citric acid and $4 \%$ sucrose and then were placed in cold storage at $5 \stackrel{\circ}{\circ} \mathrm{C}$ for period of 1,2 and 3 weeks. Vase life (days), fresh weight (\%), total chlorophyll (\%), total carbohydrate (mg / g d. w.), activity of catalase enzyme content (EU / $1 \mathrm{~g} \mathrm{f}$. w.) and amino acid of free proline content $(\mathrm{mg} / \mathrm{g} \mathrm{d}$. w.) were determined. Cold storage for one week and pulsing with using material of $\mathrm{GA}_{3}, \mathrm{BA}$ and STS produced the longest vase life, the lowest catalase enzyme activity, the lowest content chlorophyll decreasing, the highest of total carbohydrate content and the lowest amino acid of free proline content.

\section{INTRODUCTION}

The interactions of pulsing in preservatives, growth regulators also cold storage on vase life and quality of Lily (Lilium hybrida cv. Borsa) cut flowers belong to (Family Liliaceae) were investigated and this work was conducted to solve the problem of low price with increasing the quantity of flowers by storing in the refrigerator, which leads to prolong life and increase the price.

Pulsing in preservative solutions such as 8 hydroxyquinoline sulfate (8 - HQS) considered as lethal substance-microbial (fungus and bacteria) Witte et al (2014), silver thiosulfate (STS) used as inhibitor for the production of ethylene Geng et al (2009), addition of growth regulators such as gibberellic acid $\left(\mathrm{GA}_{3}\right)$ given the highest defense system and helps cell division and large size Macnish et al (2010), benzyl adenine (BA) is considered as chlorophyll content increasing morally in the leaf and prevents the decomposition of color ShimizuYumoto and Ichimura, (2013), citric acid (C. A.) facilitate increases the absorption of the nutrients, water and solution by flowers Macnish et al (2008), sucrose known also as inhibit respiration rates, the necessary energy for the performance of biological processes and his organizer role for osmositic Doi and Reid, (1995).

$\mathrm{GA}_{3}+\mathrm{BA}+\mathrm{STS}+\mathrm{C}$. A. + sucrose $4 \%$ with one week of cold storage increased vase life, fresh weight, total chlorophylls, total carbohydrates, free proline and reduced catalase enzyme activity of $L$. hybrida cut flower Macnish et al (2010), Emami et al (2011) and Geng et al (2009).

\section{MATERIALS AND METHODS}

This study was carried out in the Lab. of Hort. Dept., Faculty of Agriculture, Ain Shams Univ. Cairo, Egypt, for the two successive seasons 2012 and 2013, to investigate the effect of pulsing in preservative solutions, growth regulators and cold 
storage periods on the vase life, fresh weight, change in total chlorophyll and carbohydrates contents in Lily, as well as, amino acid of free proline and activity of catalase enzyme content of (Lilium hybrida) cv. Borsa cut flowers (orange petals).

Cut Lily flowers were obtained from private farm at $1^{\text {st }}$ of December 2012 and 2013. The flowers of Lily plant were cut at the commercial maturity after formed of floral buds and appeared colour of the petals of oldest bud with it is still closed and not opening flowers yet. Lower leaves were removed up to about $15 \mathrm{~cm}$. from the cut stem base. Then the flowers stem were cut to $50 \mathrm{~cm}$ long and placed in vases contain a recently prepared (1000 $\mathrm{cm}^{3}$ ) of the following solutions before cold storage:

1- Citric acid $200 \mathrm{ppm}+$ sucrose $4 \%$ + geberillic acid $100 \mathrm{ppm}$.

2- Citric acid 200 ppm + sucrose $4 \%$ +. benzyl adenine $0.5 \mathrm{~mm}$.

3- Citric acid 200 ppm + sucrose $4 \%$ + silver thiosulfate $1 \mathrm{~mm}$.

4- Citric acid 200 ppm + sucrose $4 \%$ + gebberillic acid $100 \mathrm{ppm}+$ benzyl adenine $0.5 \mathrm{~mm}+$ silver thiosulfate $1 \mathrm{~mm}$.

5- Control (distilled water).

The cut flowers were placed in these treatments for $24 \mathrm{~h}$ except BA. The cut flowers were placed for 20 minute only then wrapped in wax paper without damaging the flowers and put it in the refrigerator at $5^{\circ} \mathrm{C}(1,2$ and 3 weeks $)$ and dipped in standard and constant holding solution consisted of hydroxyquinoline sulfate $200 \mathrm{ppm}+$ citric acid 200 ppm + sucrose $2 \%$, to every treatment.

The following measurements were recorded (on flowers after cold storage periods):

- Vase life (days): vase life was terminated when the shape of the petals curled, wilted, failed and curved to behind for nick of flower let with yellowing of lower green leaves.

- Minimum decreasing of fresh weight of flower (\%) after storage.

- Maximum increasing of fresh weight of flowers (\%) during the experiment.

- Total chlorophylls indication in basal leaves (SPAD) after 7 and 10 days of the first of experiment and before and after the different cold storage periods.

- Total carbohydrates in leaves (mg / g D. W.) before and after the different cold storage periods.

- Amino acid of free proline in leaves ( $\mathrm{mg} / \mathrm{g} \mathrm{D}$. W.) before and after the different cold storage periods.
- Activity of the catalase enzyme (EU / g F. W.) before and after the different cold storage periods.

The experiment were performed in laboratory its temperature averaged $21 \pm 2^{\circ} \mathrm{C}$ and relative humidity $50-60 \%$ and under light intensity of 1000 lux from cool white fluorescent lumps to $12 \mathrm{~h}$ in day.

Total chlorophylls assay were measured by using Chlorophyll Metter Minolta device SPAD - 502 Wood et al (1992) the results of total chlorophylls were expressed as SPAD. It measures the relative amount of total chlorophyll present by measuring the transmittance of the leaf in two wave bands $600-700$ and $400-500 \mathrm{~nm}$ and the youngest leaves and expanded mature fully is used. The design of the experiment was a Randomized Complete Blocks in 5 treatments of solutions and 3 cold storage periods with 3 replicates and every replicate have 3 flowers. The differences between treatments were determined by using L. S. D. test according to Snedecor and Cochran, (1989) and data of the vase life, maximum fresh weight, minimum fresh weight were statistically analyzed using SAS procedure (SAS Institute Inc. 1996) while, data of the reading indication of total chlorophylls, total carbohydrates, amino acid of free proline contents and activity of the catalase enzyme was not statistically analyzed.

\section{RESULTS AND DISCUSSION}

\section{1- Vase life (days)}

Data presented in Table (1) showed that the longest vase life noticed from treatment (4) with means of (16.6 and 15.5 days) for first and second seasons, but the shortest vase life noticed from treatment (5) with values of (12.6 and 11.2 days) for first and second seasons, respectively and the differences were significant. In addition, the longest vase life occurred with cold storage period for 1 week valued by (18.6 and 20.4 days) for first and second seasons, while the shortest vase life obtained from cold storage period for 3 weeks by values of (10 and 6.6 days) for first and second seasons, respectively and the differences were significant. As well as, the longest vase life occurred with treatment (4) and one week of cold storage periods by values of (20.6 and 22.2 days) for first and second seasons, also the shortest vase life occurred with treatment (5) and 3 weeks storage period which gave (6.8 and 4.3 days) 
Table 1. Effect of preservative solutions, growth regulators and cold storage periods on vase life (days) in lily during the two seasons of 2012 and 2013

\begin{tabular}{|c|c|c|c|c|}
\hline \multirow{2}{*}{ Treatments } & \multicolumn{4}{|c|}{ First Season } \\
\hline & 1 Week & 2 Weeks & 3 Weeks & Mean \\
\hline \multirow{5}{*}{$\begin{array}{l}\text { 1- C. A. } 200 \mathrm{ppm}+\text { sucrose } 4 \%+\mathrm{GA}_{3} 100 \mathrm{ppm} \\
\text { 2- C. A. } 200 \mathrm{ppm}+\text { sucrose } 4 \%+\mathrm{BA} 0.5 \mathrm{ml} \mathrm{mol} \\
\text { 3- C. A. } 200 \mathrm{ppm}+\text { sucrose } 4 \%+\mathrm{STS} 1 \mathrm{ml} \mathrm{mol} \\
\text { 4- C. A. } 200 \mathrm{ppm}+\text { sucrose } 4 \%+\mathrm{GA}_{3} 100 \mathrm{ppm}+ \\
\text { BA } 0.5 \mathrm{ml} \mathrm{mol} \mathrm{+} \mathrm{STS} 1 \mathrm{ml} \mathrm{mol} \\
\text { 5- Distilled water (control) }\end{array}$} & $18.5 \mathrm{AB}$ & 13.5 DEF & $9.3 \mathrm{GH}$ & $13.8 \mathrm{BC}$ \\
\hline & 18.6 AB & $16.5 \mathrm{BCD}$ & $12.9 \mathrm{EF}$ & $16.0 \mathrm{~A}$ \\
\hline & $19.2 \mathrm{AB}$ & 16.3 BCD & $9.5 \mathrm{GH}$ & $15.0 \mathrm{AB}$ \\
\hline & $20.6 \mathrm{~A}$ & 18.0 ABC & $11.4 \mathrm{FG}$ & $16.6 \mathrm{~A}$ \\
\hline & 16.2 BCD & 14.9 CDE & $6.8 \mathrm{H}$ & $12.6 \mathrm{C}$ \\
\hline Mean & $18.6 \mathrm{~A}$ & $15.8 \mathrm{~B}$ & $10.0 \mathrm{C}$ & \\
\hline \multirow{2}{*}{ Treatments } & \multicolumn{4}{|c|}{ Second Season } \\
\hline & 1 Week & 2 Weeks & 3 Weeks & Mean \\
\hline \multirow{5}{*}{$\begin{array}{l}\text { 1- C. A. } 200 \mathrm{ppm}+\text { sucrose } 4 \%+\mathrm{GA}_{3} 100 \mathrm{ppm} \\
\text { 2- C. A. } 200 \mathrm{ppm}+\text { sucrose } 4 \%+\mathrm{BA} 0.5 \mathrm{ml} \mathrm{mol} \\
\text { 3- C. A. } 200 \mathrm{ppm}+\text { sucrose } 4 \%+\mathrm{STS} 1 \mathrm{ml} \mathrm{mol} \\
\text { 4- C. A. } 200 \mathrm{ppm}+\text { sucrose } 4 \%+\mathrm{GA}_{3} 100 \mathrm{ppm}+ \\
\text { BA } 0.5 \mathrm{ml} \mathrm{mol}+\text { STS } 1 \mathrm{ml} \mathrm{mol} \\
\text { 5- Distilled water (control) }\end{array}$} & $21.3 \mathrm{~A}$ & 13.7 DE & $7.2 \mathrm{~F}$ & $14.0 \mathrm{~B}$ \\
\hline & $20.5 \mathrm{~A}$ & 14.2 CDE & $7.3 \mathrm{~F}$ & $14.0 \mathrm{~B}$ \\
\hline & $21.3 \mathrm{~A}$ & $15.2 \mathrm{BCD}$ & $6.2 \mathrm{FG}$ & $14.2 \mathrm{~B}$ \\
\hline & $22.2 \mathrm{~A}$ & $16.2 \mathrm{BC}$ & $8.1 \mathrm{~F}$ & $15.5 \mathrm{~A}$ \\
\hline & $16.5 \mathrm{~B}$ & $12.8 \mathrm{E}$ & $4.3 \mathrm{G}$ & $11.2 \mathrm{C}$ \\
\hline Mean & $20.4 \mathrm{~A}$ & 14.4 B & $6.6 \mathrm{C}$ & \\
\hline
\end{tabular}

for first and second seasons, respectively and the differences were significant. These results were in agreement with Rabiza-Swider et al (2012) who found that the preservative increased vase life of cut oriental lily 'Helvetia' flowers by using the chemicals treatment after cutting. Also, Geng et al (2009) found that the application of STS to Lily 'Mantissa' flowers prolonged the inflorescence longevity and improved the quality and the cold-stored cut flowers showed more improvements in the quality than the cut flowers without cold storage. Likewise, SunAe et al (2009) reported that an increase of the vase life of cut lilies (Lilium) Oriental hybrid 'Casa Blanca' by using various chemical holding solutions and floral preservatives.

\section{2- Minimum decreasing of fresh weight per- centage of flowers (\%)}

Data presented in Table (2) showed that the minimum decreasing of fresh weight noticed from treatments ( 1 and 3 ) for first and second seasons by values of $(7.7$ and $7.3 \%)$, also the maximum decreasing of fresh weight occurred with treatments (2 and 5 ) for first and second seasons by values of (11.7 and $10.5 \%$ ), respectively and the differences were significant. In addition, the minimum decreasing of fresh weight obtained from one week of cold storage periods which gave (3.9 and
$3.6 \%)$ for first and second seasons, while the maximum decreasing of fresh weight found with three weeks of cold storage periods with values of (17.1 and $12.6 \%$ ) for first and second seasons, respectively and the differences were significant. Also, the minimum decreasing of fresh weight resulted from treatments ( 3 and 2 ) with 1 week cold storage period which gave $(2.5$ and $2.5 \%)$ for first and second seasons, but the maximum decreasing of fresh weight noticed from treatments (2 and 5 ) with 3 weeks cold storage period by values of $(20$ and $14.8 \%$ ) for first and second seasons, respectively and the differences were significant. These results were in agreement with Meeteren et al (2000) who indicated that hold Chrysanthemum cv. Cassa cut flowers in deionized water gave a sharp decrease in fresh weight after 1 - 3 days and after 4 days in deionized water occurred hydraulic resistance in the basal part of the stem was 50 times the value of fresh cut flowers and 7 times the value in tap water. Also, Meeteren et al (2001) showed that fresh weight of Chrysanthemum morifolium (Dendranthema grandiflorum) flowers started to decrease after three days in deionized water, but did not decrease within the 7 days of the experiment in tap water and when placed at $\mathrm{AgNO}_{3}$ also. Also, Han, (2001) noticed that the cold storage (3.3 degrees $C$ ) reduced the fresh weight of open cut flowers of Asiatic and oriental lilies (Lilium sp.). 
Table 2. Effect of preservative solutions, growth regulators and cold storage periods on minimum decreasing of fresh weight percentage (\%) in lily during the two seasons of 2012 and 2013

\begin{tabular}{|c|c|c|c|c|}
\hline \multirow{2}{*}{ Treatments } & \multicolumn{4}{|c|}{ First Season } \\
\hline & 1 Week & 2 Weeks & 3 Weeks & Mean \\
\hline \multirow{5}{*}{$\begin{array}{l}\text { 1- C. A. } 200 \mathrm{ppm}+\text { sucrose } 4 \%+\mathrm{GA}_{3} 100 \mathrm{ppm} \\
\text { 2- C. A. } 200 \mathrm{ppm}+\text { sucrose } 4 \%+\mathrm{BA} 0.5 \mathrm{ml} \mathrm{mol} \\
\text { 3- C. A. } 200 \mathrm{ppm}+\text { sucrose } 4 \%+\mathrm{STS} 1 \mathrm{ml} \mathrm{mol} \\
\text { 4- C. A. } 200 \mathrm{ppm}+\text { sucrose } 4 \%+\mathrm{GA}_{3} 100 \mathrm{ppm}+ \\
\text { BA } 0.5 \mathrm{ml} \mathrm{mol}+\text { STS } 1 \mathrm{ml} \mathrm{mol} \\
\text { 5- Distilled water (control) }\end{array}$} & $3.4 \mathrm{IJ}$ & $7.0 \mathrm{GH}$ & $12.7 \mathrm{D}$ & $7.7 \mathrm{D}$ \\
\hline & 4.21 & $11.1 \mathrm{E}$ & $20.0 \mathrm{~A}$ & $11.7 \mathrm{~A}$ \\
\hline & $2.5 \mathrm{~J}$ & $7.6 \mathrm{GH}$ & $19.1 \mathrm{~A}$ & $9.7 \mathrm{~B}$ \\
\hline & $3.2 \mathrm{lJ}$ & $7.9 \mathrm{G}$ & $15.9 \mathrm{C}$ & $9.0 \mathrm{C}$ \\
\hline & $6.3 \mathrm{H}$ & $9.6 \mathrm{~F}$ & $17.8 \mathrm{~B}$ & $11.3 \mathrm{~A}$ \\
\hline Mean & $3.9 \mathrm{C}$ & $8.6 \mathrm{~B}$ & $17.1 \mathrm{~A}$ & \\
\hline \multirow{2}{*}{ Treatments } & \multicolumn{4}{|c|}{ Second Season } \\
\hline & 1 Week & 2 Weeks & 3 Weeks & Mean \\
\hline 1- C. A. $200 \mathrm{ppm}+$ sucrose $4 \%+\mathrm{GA}_{3} 100 \mathrm{ppm}$ & $3.3 \mathrm{G}$ & $11.4 \mathrm{C}$ & $13.5 \mathrm{~B}$ & $9.4 \mathrm{~B}$ \\
\hline 2- C. A. $200 \mathrm{ppm}+$ sucrose $4 \%+$ BA $0.5 \mathrm{ml} \mathrm{mol}$ & $2.5 \mathrm{G}$ & $9.3 \mathrm{D}$ & $10.7 \mathrm{C}$ & $7.5 \mathrm{C}$ \\
\hline 3- C. A. $200 \mathrm{ppm}+$ sucrose $4 \%+$ STS $1 \mathrm{ml} \mathrm{mol}$ & $3.0 \mathrm{G}$ & 8.1 DE & $10.9 \mathrm{C}$ & $7.3 \mathrm{C}$ \\
\hline $\begin{array}{l}\text { 4- C. A. } 200 \mathrm{ppm}+\text { sucrose } 4 \%+\mathrm{GA}_{3} 100 \mathrm{ppm}+ \\
\text { BA } 0.5 \mathrm{ml} \mathrm{mol}+\mathrm{STS} 1 \mathrm{ml} \mathrm{mol}\end{array}$ & $3.6 \mathrm{G}$ & $7.4 \mathrm{E}$ & $13.1 \mathrm{~B}$ & $8.0 \mathrm{C}$ \\
\hline 5- Distilled water (control) & $5.4 \mathrm{~F}$ & $11.4 \mathrm{C}$ & $14.8 \mathrm{~A}$ & $10.5 \mathrm{~A}$ \\
\hline Mean & $3.6 \mathrm{C}$ & $9.5 \mathrm{~B}$ & $12.6 \mathrm{~A}$ & \\
\hline
\end{tabular}

\section{3- Maximum increasing of fresh weight per- centage of flower (\%)}

Data presented in Table (3) showed that the maximum fresh weight occurred with treatment (4) which gave (17.2 and $17 \%$ ) for first and second seasons, while the minimum fresh weight formed with treatment (5) with values of (12.7 and $11.6 \%$ ) for first and second seasons, respectively and the differences were significant. The maximum fresh weight obtained from cold storage for three weeks by values of (21.1 and $18.7 \%$ ) for first and second seasons, but the minimum fresh weight noticed with cold storage for one week with value of $(9.7$ and $8.5 \%$ ) for first and second seasons, respectively and the differences were significant. The addition of maximum fresh weight consisted of treatment (4) with three weeks of cold storage with values of (27.3 and $23.5 \%)$ for first and second seasons, also the minimum fresh weight obtained from treatment (5) with one week of cold storage and treatment (2) with one week of cold storage with means of (7.8 and $7.5 \%)$ for first and second seasons, respectively and the differences were significant. These results were in agreement with Elanchezhian and Srivastava, (2001) who found that chrysanthemum cut flowers fresh weight was greatest in flowers kept in GA or control solution.
As well as, Emami et al (2011) found that treating lily (Lilium longiflorum) with $\mathrm{GA}_{3}$ and interaction with $B A$ on initial fresh weight were highest and there were positive correlation in $9^{\text {th }}$ and $12^{\text {th }}$ days. Also, Meeteren et al (2000) found that the change in fresh weight of chrysanthemum cv. Cassa cut flowers was positively enhanced during the vase life in a solution containing calcium chloride $\left(\mathrm{CaCl}_{2}\right)$ at concentrations commonly.

\section{4- Percentage of total chlorophyll decreasing} (\%)

Data presented in Table (4) showed that the lowest decreasing of chlorophyll content occurred with treatment (4) and one week period of cold storage with values of ( 2 and $2 \%$ ) for first and second seasons, but the highest decreasing of chlorophyll content occurred with treatment (5) with three weeks period of cold storage with values of (75 and $70 \%$ ) for first and second seasons, respectively. These results were in agreement with Emami et al (2011) in their study on lily ( $L$. longiflorum) longevity found that $\mathrm{GA}_{3}$ and interaction with $\mathrm{BA}$ on total chlorophyll content were highest significant and positive correlation in $9^{\text {th }}$ and $12^{\text {th }}$ days. Also, Zhenghong et al (2007) found that biochemical effects on safe cut flowers of Oriental 
Table 3. Effect of preservative solutions, growth regulators and cold storage periods on maximum increasing of fresh weight percentage (\%) in lily during the two seasons of 2012 and 2013

\begin{tabular}{|c|c|c|c|c|}
\hline \multirow{2}{*}{ Treatments } & \multicolumn{4}{|c|}{ First Season } \\
\hline & 1 Week & 2 Weeks & 3 Weeks & Mean \\
\hline 1- C. A. $200 \mathrm{ppm}+$ sucrose $4 \%+\mathrm{GA}_{3} 100 \mathrm{ppm}$ & $11.5 \mathrm{EF}$ & 11.3 EF & 16.5 CDE & $13.1 \mathrm{BC}$ \\
\hline 2- C. A. $200 \mathrm{ppm}+$ sucrose $4 \%+$ BA $0.5 \mathrm{ml} \mathrm{mol}$ & $10.9 \mathrm{EF}$ & 15.3 DE & $22.3 \mathrm{AB}$ & $16.2 \mathrm{AB}$ \\
\hline 3- C. A. $200 \mathrm{ppm}+$ sucrose $4 \%+$ STS $1 \mathrm{ml} \mathrm{mol}$ & $9.2 \mathrm{~F}$ & 15.6 DE & $21.5 \mathrm{BC}$ & 15.4 ABC \\
\hline $\begin{array}{l}\text { 4- C. A. } 200 \mathrm{ppm}+\text { sucrose } 4 \%+\mathrm{GA}_{3} 100 \mathrm{ppm}+ \\
\text { BA } 0.5 \mathrm{ml} \mathrm{mol}+\text { STS } 1 \mathrm{ml} \mathrm{mol}\end{array}$ & $9.2 \mathrm{~F}$ & 15.2 DE & $27.3 \mathrm{~A}$ & $17.2 \mathrm{~A}$ \\
\hline 5- Distilled water (control) & $7.8 \mathrm{~F}$ & 12.5 DEF & $17.9 \mathrm{BCD}$ & $12.7 \mathrm{C}$ \\
\hline Mean & $9.7 \mathrm{C}$ & $14.0 \mathrm{~B}$ & $21.1 \mathrm{~A}$ & \\
\hline \multirow{2}{*}{ Treatments } & \multicolumn{4}{|c|}{ Second Season } \\
\hline & 1 Week & 2 Weeks & 3 Weeks & Mean \\
\hline 1- C. A. $200 \mathrm{ppm}+$ sucrose $4 \%+\mathrm{GA}_{3} 100 \mathrm{ppm}$ & $8.5 \mathrm{EFG}$ & 15.4 BCD & $20.4 \mathrm{AB}$ & $14.7 \mathrm{AB}$ \\
\hline 2- C. A. $200 \mathrm{ppm}+$ sucrose $4 \%+$ BA $0.5 \mathrm{ml} \mathrm{mol}$ & $7.5 \mathrm{G}$ & 15.8 BCD & $18.9 \mathrm{AB}$ & 14.1 BC \\
\hline 3- C. A. $200 \mathrm{ppm}+$ sucrose $4 \%+$ STS $1 \mathrm{ml} \mathrm{mol}$ & $9.2 \mathrm{EFG}$ & 13.1 DEF & 17.2 BCD & $13.2 \mathrm{BC}$ \\
\hline $\begin{array}{l}\text { 4- C. A. } 200 \mathrm{ppm}+\text { sucrose } 4 \%+\mathrm{GA}_{3} 100 \mathrm{ppm}+ \\
\text { BA } 0.5 \mathrm{ml} \mathrm{mol}+\text { STS } 1 \mathrm{ml} \mathrm{mol}\end{array}$ & 8.9 EFG & $18.5 \mathrm{ABC}$ & $23.5 \mathrm{~A}$ & $17.0 \mathrm{~A}$ \\
\hline 5- Distilled water (control) & 8.1 FG & 13.2 DEF & 13.5 CDE & $11.6 \mathrm{C}$ \\
\hline Mean & $8.5 \mathrm{C}$ & $15.2 \mathrm{~B}$ & 18.7 A & \\
\hline
\end{tabular}

Table 4. Effect of preservative solutions, growth regulators and cold storage periods on mean of decreasing rate of total chlorophyll (\%) in leaves of lily during the two seasons of 2012 and 2013

\begin{tabular}{|c|c|c|c|}
\hline \multirow{2}{*}{ Cold Storage $\left(5^{\circ} \mathrm{C}\right)$} & \multicolumn{3}{|c|}{ First Season } \\
\hline & 1 Week & 2 Weeks & 3 Weeks \\
\hline 1- C. A. $200 \mathrm{ppm}+$ sucrose $4 \%+\mathrm{GA}_{3} 100 \mathrm{ppm}$ & 8 & 33 & 55 \\
\hline 2- C. A. $200 \mathrm{ppm}+$ sucrose $4 \%+$ BA $0.5 \mathrm{ml} \mathrm{mol}$ & 5 & 25 & 45 \\
\hline 3- C. A. $200 \mathrm{ppm}+$ sucrose $4 \%+$ STS $1 \mathrm{ml} \mathrm{mol}$ & 10 & 35 & 60 \\
\hline $\begin{array}{l}\text { 4- C. A. } 200 \mathrm{ppm}+\text { sucrose } 4 \%+\mathrm{GA}_{3} 100 \mathrm{ppm}+\mathrm{BA} \\
0.5 \mathrm{ml} \mathrm{mol}+\mathrm{STS} 1 \mathrm{ml} \mathrm{mol}\end{array}$ & 2 & 21 & 35 \\
\hline 5- Distilled water (control) & 15 & 45 & 75 \\
\hline \multirow{2}{*}{ Treatments } & \multicolumn{3}{|c|}{ Second Season } \\
\hline & 1 Week & 2 Weeks & 3 Weeks \\
\hline 1- C. A. $200 \mathrm{ppm}+$ sucrose $4 \%+\mathrm{GA}_{3} 100 \mathrm{ppm}$ & 6 & 30 & 57 \\
\hline 2- C. A. $200 \mathrm{ppm}+$ sucrose $4 \%+$ BA $0.5 \mathrm{ml} \mathrm{mol}$ & 5 & 27 & 48 \\
\hline 3- C. A. $200 \mathrm{ppm}+$ sucrose $4 \%+$ STS $1 \mathrm{ml} \mathrm{mol}$ & 8 & 33 & 51 \\
\hline $\begin{array}{l}\text { 4- C. A. } 200 \mathrm{ppm}+\text { sucrose } 4 \%+\mathrm{GA}_{3} 100 \mathrm{ppm}+\mathrm{BA} \\
0.5 \mathrm{ml} \mathrm{mol}+\mathrm{STS} 1 \mathrm{ml} \mathrm{mol}\end{array}$ & 2 & 23 & 38 \\
\hline 5- Distilled water (control) & 17 & 40 & 70 \\
\hline
\end{tabular}


hybrid lily 'Acapulco' after treating by chemical preservation solutions and cold storage for a week at $2+$ or $-1^{\circ} \mathrm{C}$ improved the quality included total chlorophyll content in the leaves and petals and other physiological indicators.

\section{5- Total carbohydrates content (mg / 1 g D. W.)}

Data presented in Table (5) showed that the highest total carbohydrates content recorded with treatment (4) with cold storage period for one week which gave (46.2 and $38.2 \mathrm{mg} / \mathrm{g} \mathrm{D}$. W.) for first and second seasons, while the lowest total carbohydrate content found with treatment (5) and cold storage period for three weeks which gave (8.9 and $6.2 \mathrm{mg} / \mathrm{g} \mathrm{D}$. W.) for first and second seasons, respectively. These results were in agreement with Meulen-Muisers et al (2001) in his work on Asiatic hybrid lilies to determine the importance of carbohydrate within the most mature floral bud stage and largest buds tepal size of inflorescences, whereas total carbohydrate content of tepal amounted to $75 \%$ as indicate to the tepal carbohydrate content play a major and important role. While, SunAe et al (2009) showed that cut lilies (Lilium Oriental hybrid 'Casa Blanca') significantly maintained high levels of sucrose and total sugar for a long time as compared with the control (distilled water) and these results indicated that the vase life and carbohydrate supply have a strong correlation.

Table 5. Effect of preservative solutions, growth regulators and cold storage periods on mean of total carbohydrates content (mg / g D. W.) in lily during the two seasons of 2012 and 2013

\begin{tabular}{|c|c|c|c|}
\hline \multirow{2}{*}{ Treatments } & \multicolumn{3}{|c|}{ First Season } \\
\hline & 1 Week & 2 Weeks & 3 Weeks \\
\hline \multirow{5}{*}{$\begin{array}{l}\text { 1- C. A. } 200 \mathrm{ppm}+\text { sucrose } 4 \%+\mathrm{GA}_{3} 100 \mathrm{ppm} \\
\text { 2- C. A. } 200 \mathrm{ppm}+\text { sucrose } 4 \%+\mathrm{BA} 0.5 \mathrm{ml} \mathrm{mol} \\
\text { 3- C. A. } 200 \mathrm{ppm}+\text { sucrose } 4 \%+\mathrm{STS} 1 \mathrm{ml} \mathrm{mol} \\
\text { 4- C. A. } 200 \mathrm{ppm}+\text { sucrose } 4 \%+\mathrm{GA}_{3} 100 \mathrm{ppm}+\mathrm{BA} 0.5 \mathrm{ml} \\
\text { mol + STS } 1 \mathrm{ml} \mathrm{mol} \\
\text { 5- Distilled water (control) }\end{array}$} & 36.2 & 26.9 & 14.2 \\
\hline & 43.2 & 18.9 & 19.9 \\
\hline & 43.2 & 30.2 & 16.5 \\
\hline & 46.2 & 32.2 & 26.2 \\
\hline & 26.2 & 16.9 & 8.9 \\
\hline \multirow{2}{*}{ Treatments } & \multicolumn{3}{|c|}{ Second Season } \\
\hline & 1 Week & 2 Weeks & 3 Weeks \\
\hline 1- C. A. $200 \mathrm{ppm}+$ sucrose $4 \%+\mathrm{GA}_{3} 100 \mathrm{ppm}$ & 24.9 & 17.2 & 7.9 \\
\hline 2- C. A. $200 \mathrm{ppm}+$ sucrose $4 \%+$ BA $0.5 \mathrm{ml} \mathrm{mol}$ & 23.2 & 19.9 & 13.2 \\
\hline 3- C. A. $200 \mathrm{ppm}+$ sucrose $4 \%+$ STS $1 \mathrm{ml} \mathrm{mol}$ & 30.2 & 23.2 & 9.9 \\
\hline $\begin{array}{l}\text { 4- C. A. } 200 \mathrm{ppm}+\text { sucrose } 4 \%+\mathrm{GA}_{3} 100 \mathrm{ppm}+\mathrm{BA} 0.5 \mathrm{ml} \\
\mathrm{mol}+\mathrm{STS} 1 \mathrm{ml} \mathrm{mol}\end{array}$ & 38.2 & 29.2 & 22.2 \\
\hline 5- Distilled water (control) & 22.2 & 15.5 & 6.2 \\
\hline
\end{tabular}

\section{6- Free proline content (mg / g D. W.)}

Data presented in Table (6) showed that the minimum free proline content obtained from treatment (5) with 1 week of cold storage periods by result of (9.5 and $11 \mathrm{mg} / \mathrm{g} \mathrm{D}$. W.) for first and second seasons, also the maximum free proline content noticed with treatment (4) and 3 weeks of cold storage periods recorded at (97.7 and $64 \mathrm{mg} / \mathrm{g} \mathrm{D}$. W.) for first and second seasons, respectively. These results were in agreement with RabizaSwider et al (2012) who found that during the senescence reduced free proline in cut oriental lily
'Helvetia' flowers because the preservative delayed accumulation of proline. Also, Geng et al (2009) found that treating cut OT Lily 'Mantissa' flowers by the application of STS delayed the accumulation of proline.

\section{7- Activity of catalase enzyme (EU / 1 g F. W.)}

Data presented in Table (7) showed that the minimum activity of catalase enzyme content recorded from the interaction of treatments (2 and 3 ) with one week from cold storage times which gave values of (39.4 and $35.9 \mathrm{EU} / 1 \mathrm{~g} \mathrm{~F}$. W.) for first 
Table 6. Effect of preservative solutions, growth regulators and cold storage periods on mean of free proline content (mg / g D. W.) in lily during the two seasons of 2012 and 2013

\begin{tabular}{|c|c|c|c|}
\hline \multirow{2}{*}{ Cold Storage $(5 \stackrel{\circ}{ } \mathrm{C})$} & \multicolumn{3}{|c|}{ First Season } \\
\hline & 1 Week & 2 Weeks & 3 Weeks \\
\hline 1- C. A. $200 \mathrm{ppm}+$ sucrose $4 \%+\mathrm{GA}_{3} 100 \mathrm{ppm}$ & 13.6 & 45.5 & 76.7 \\
\hline 2- C. A. $200 \mathrm{ppm}+$ sucrose $4 \%+$ BA $0.5 \mathrm{ml} \mathrm{mol}$ & 13.1 & 46.1 & 63.7 \\
\hline 3- C. A. $200 \mathrm{ppm}+$ sucrose $4 \%+$ STS $1 \mathrm{ml} \mathrm{mol}$ & 11.4 & 42.7 & 77.7 \\
\hline $\begin{array}{l}\text { 4- C. A. } 200 \mathrm{ppm}+\text { sucrose } 4 \%+\mathrm{GA}_{3} 100 \mathrm{ppm}+\mathrm{BA} 0.5 \mathrm{ml} \\
\mathrm{mol}+\mathrm{STS} 1 \mathrm{ml} \mathrm{mol}\end{array}$ & 18.1 & 55.2 & 97.7 \\
\hline 5- Distilled water (control) & 9.5 & 36.0 & 48.3 \\
\hline \multirow{2}{*}{ Treatments } & \multicolumn{3}{|c|}{ Second Season } \\
\hline & 1 Week & 2 Weeks & 3 Weeks \\
\hline 1- C. A. $200 \mathrm{ppm}+$ sucrose $4 \%+\mathrm{GA}_{3} 100 \mathrm{ppm}$ & 16.9 & 44.2 & 59.2 \\
\hline 2- C. A. $200 \mathrm{ppm}+$ sucrose $4 \%+$ BA $0.5 \mathrm{ml} \mathrm{mol}$ & 19.2 & 33.3 & 59.2 \\
\hline 3- C. A. $200 \mathrm{ppm}+$ sucrose $4 \%+$ STS $1 \mathrm{ml} \mathrm{mol}$ & 15.0 & 36.0 & 60.6 \\
\hline $\begin{array}{l}\text { 4- C. A. } 200 \mathrm{ppm}+\text { sucrose } 4 \%+\mathrm{GA}_{3} 100 \mathrm{ppm}+\mathrm{BA} 0.5 \mathrm{ml} \\
\mathrm{mol}+\mathrm{STS} 1 \mathrm{ml} \mathrm{mol}\end{array}$ & 34.9 & 47.0 & 64.0 \\
\hline 5- Distilled water (control) & 11.0 & 30.2 & 55.2 \\
\hline
\end{tabular}

Table 7. Effect of preservative solutions, growth regulators and cold storage periods on mean of activity of catalase enzyme content (EU / 1 g F. W.) in lily during the two seasons of 2012 and 2013

\begin{tabular}{|c|c|c|c|}
\hline \multirow{2}{*}{ Cold Storage (5 $\stackrel{\circ}{ } \mathrm{C})$} & \multicolumn{3}{|c|}{ First Season } \\
\hline & 1 Week & 2 Weeks & 3 Weeks \\
\hline 1- C. A. $200 \mathrm{ppm}+$ sucrose $4 \%+\mathrm{GA}_{3} 100 \mathrm{ppm}$ & 47.3 & 67.5 & 110.5 \\
\hline 2- C. A. $200 \mathrm{ppm}+$ sucrose $4 \%+$ BA $0.5 \mathrm{ml} \mathrm{mol}$ & 39.4 & 77.6 & 116.6 \\
\hline 3- C. A. $200 \mathrm{ppm}+$ sucrose $4 \%+$ STS $1 \mathrm{ml} \mathrm{mol}$ & 45.3 & 55.4 & 104.4 \\
\hline $\begin{array}{l}\text { 4- C. A. } 200 \mathrm{ppm}+\text { sucrose } 4 \%+\mathrm{GA}_{3} 100 \mathrm{ppm}+\mathrm{BA} 0.5 \mathrm{ml} \\
\mathrm{mol}+\mathrm{STS} 1 \mathrm{ml} \mathrm{mol}\end{array}$ & 49.5 & 79.3 & 86.5 \\
\hline 5- Distilled water (control) & 148.6 & 188.9 & 249.6 \\
\hline \multirow{2}{*}{ Treatments } & \multicolumn{3}{|c|}{ Second Season } \\
\hline & 1 Week & 2 Weeks & 3 Weeks \\
\hline 1- C. A. $200 \mathrm{ppm}+$ sucrose $4 \%+\mathrm{GA}_{3} 100 \mathrm{ppm}$ & 37.9 & 67.1 & 123.1 \\
\hline 2- C. A. $200 \mathrm{ppm}+$ sucrose $4 \%+$ BA $0.5 \mathrm{ml} \mathrm{mol}$ & 44.6 & 69.8 & 111.8 \\
\hline 3- C. A. $200 \mathrm{ppm}+$ sucrose $4 \%+$ STS $1 \mathrm{ml} \mathrm{mol}$ & 35.9 & 87.1 & 123.7 \\
\hline $\begin{array}{l}\text { 4- C. A. } 200 \mathrm{ppm}+\text { sucrose } 4 \%+\mathrm{GA}_{3} 100 \mathrm{ppm}+\mathrm{BA} 0.5 \mathrm{ml} \\
\mathrm{mol}+\mathrm{STS} 1 \mathrm{ml} \mathrm{mol}\end{array}$ & 47.6 & 78.8 & 109.6 \\
\hline 5- Distilled water (control) & 135.1 & 180.5 & 251.7 \\
\hline
\end{tabular}


and second seasons, but the maximum activity of catalase enzyme content produced with treatment (5) and three weeks from cold storage times valued with (249.6 and 251.7 EU / $1 \mathrm{~g} \mathrm{~F}$. W.) for first and second seasons, respectively. These data were in agreement with Luo and Li, (2005) in his work on senescence of cut flowers of lily (Lilium longiflorum), he found that the pre-treatment solution for $12 \mathrm{~h}$ contained $4 \%$ sucrose and $300 \mathrm{mg} /$ litre of 8 - hydroxyquinoline citrate $(8-\mathrm{HQC})$ increased the activity of catalase (CAT). Also, Ranwala and Miller, (2000) found that Lilium cv. Stargazer, plants were held for 2 weeks at 4 degrees $C$ in darkness after pretreatment by foliar sprays with $100 \mathrm{mg} \mathrm{GA} 4_{4+7}$ / litre, was prevented rapid leaf senescence and shifting from 4 to 22 degrees $C$, including rapid loss of catalase activity were determined during storage at 4 degrees $\mathrm{C}$ and during 6 days after transferring the plants to 22 degrees c.

\section{REFERENCES}

Doi, M. and Reid, S.M. 1995. Sucrose Improves the Postharvest Life of Cut Flowers of a Hybrid Limonium. Post. Biol. Tech., Hort. Sci., 30(5), 1058-1060.

Elanchezhian, R. and Srivastava, G.C. 2001. Effect of growth regulators on senescence of chrysanthemum flowers. Indian J. Plant Phys., 6(3), 233-243.

Emami, H., Saeidnia, M., Olfati, J.A. and Hasani, M. 2011. Study on lily longevity treated with growth regulator $\left(\mathrm{GA}_{3}\right.$ and $\left.\mathrm{BA}\right)$ by path analysis. Am.-Eurasian J. Agric. Environ. Sci., 10(5), 814-820.

Geng, X.M., Jun, L., Lu, J.G., Hu, F.K. and Okubo, H. 2009. Effects of cold storage and different pulsing treatments on postharvest quality of cut OT Lily 'Mantissa' flowers. J. Fac. Agric., Kyushu Univ., 54(1), 41-45.

Han, S.S. 2001. Benzyl adenine and gibberellins improve postharvest quality of cut Asiatic and Oriental lilies. Hort. Sci., 36 (4), 741-745.

Luo, H.Y. and Li, J.Z. 2005. Effects of pretreatment solution containing $\mathrm{B}_{9}$ on senescence of cut flower of lily. Plant Phys. Commun., 41(1), 34-36.

Macnish, A.J., Jiang, C.Z. and Reid, S.M. 2010. Treatment with thidiazuron improves opening and vase life of iris flowers. Post. Biol. Tech., 56(1), 77-84.

Macnish, A.J., Leonard, R.T. and Nell, T.A. 2008. Treatment with chlorine dioxide extends the vase life of selected cut flowers. Post. Biol. Tech., 50(2/3), 197-207.
Meeteren, U., Gelder, H. and leperen, W. 2000. Reconsideration of the use of deionized water as vase water in postharvest experiments on cut flowers. Post. Biol. Tech., 18(2), 169-181.

Meeteren, U., Gelder, A., leperen, W. and Slootweg, C. 2001. Should we reconsider the use of deionized water as control vase solutions?. Acta Hort., 543, 257-262.

Meulen-Muisers, J.J.M., Oeveren, J.C., Plas, L.H.W. and Tuyl, J.M. 2001. Postharvest flower development in Asiatic hybrid lilies as related to tepal carbohydrate status. Post. Biol. Tech., 21(2), 201-211.

Rabiza-Swider, J., Skutnik, E. and Chodorska, M. 2012. The effect of growth regulators and preservative on senescence of cut oriental lily 'Helvetia'. Acta Sci. Polo. - Hort. Cult., 11(5), 183-194.

Ranwala, A.P. and Miller, W.B. 2000. Preventive mechanisms of gibberellin ${ }_{4+7}$ and light on low-temperature-induced leaf senescence in Lilium cv. Stargazer. Post. Biol. Tech., 19(1), 85-92.

SAS Institute Inc. 1996. SAS/STAT Software: Changes and Enhancements through Release 6.12, Cary, NC, SAS Institute Inc.

Shimizu-Yumoto, H. and Ichimura, K. 2013. Postharvest characteristics of cut dahlia flowers with a focus on ethylene and effectiveness of 6benzylaminopurine treatments in extending vase life. Post. Biol. Tech., 86, 479-486.

Snedecor, G.W. and Cochran, W.G. 1989. Statistical methods. Eighth Edi., lowa State Univ. Press.

SunAe, H., PoongOk, L. and JongSuk, L. 2009. Effect of holding solutions on vase life and sugar content during flower senescence of cut Lilium oriental hybrid 'Casa Blanca'. Korean J. Hort. Sci. Tech., 27(2), 263-268.

Witte, Y., Doorn, G., Wouter, W.G. and Harkema, H. 2014. Effect of antimicrobial compounds on cut Gerbera flowers: Poor relation between stem bending and numbers of bacteria in the vase water. Post. Biol. Tech., 91, 78-83.

Wood, C.W., Reeves, D.W. and Himelrick, D.G. 1992. Relationships between chlorophyll meter readings and leaf chlorophyll concentration. $\mathrm{N}$ status and crop yield. A Rev.: Proc. Agro. Sco. N.Z., 23, 1-9.

Zhenghong, A.L., Jai, C. and Zhong, L.H. 2007. The physiological effects of fresh keep and pretreatment solutions on the transport of cold storage of cut flowers "Acapulco". Master Prog. Life Sci., Natl. Chung Hsing U., p. 101. 